\title{
Od Roentgena (120 lat) do stereotaktycznej radiochirurgii
}

\author{
Bogusław Maciejewski
}

W opracowaniu przedstawiono mało znane szczegóły z pierwszych lat po odkryciu przez Roentgena promieniowania X. Postępy w radioterapii w okresie 120 lat są dyskutowane i ilustrowane diagramami milowych osiągnięć w zakresie fizyki, technologii i metod wdrażanych do radioterapii. Dyskusja koncentruje się na dwóch obszarach: „fizyka vs bio-

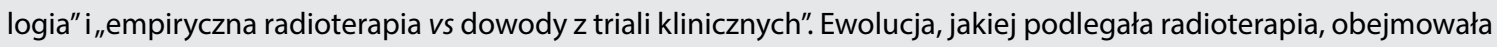
dwa okresy:„,szkołę Patersona” (przez pierwsze 50 lat) oraz obowiązującą od 1968 roku aż do dnia dzisiejszego „szkołę Fletchera". Osiągnięcia doświadczalnej i klinicznej radiobiologii stworzyły racjonalne fundamenty dla tej drugiej. W oparciu o doświadczenia lat 50.-70. odkryto i zdefiniowano prawie wszystkie mechanizmy odpowiedzi nowotworu i tkanek zdrowych na promieniowanie. Przez ponad 80 lat postęp w radioterapii był wynikiem gromadzenia doświadczenia w zakresie radioterapii empirycznej. Wyniki badań retrospektywnych stanowiły podstawę dla inicjowania triali klinicznych, jednak wiele tzw. „opartych na dowodach” triali jest niejasnych i oferuje średni zysk terapeutyczny jako „dowodowy” drogowskaz dla indywidualizacji leczenia. Wyniki przykładowych triali klinicznych są krytycznie dyskutowane z sugestią ostrożnej ich interpretacji, z wykorzystaniem logiki i zdrowego rozsądku klinicznego. Badania z zakresu genetyki i biologii molekularnej jasno dowodzą, że każdy nowotwór ma własne indywidualne „linie papilarne", które wskazują całej onkologii, włącznie z radioterapią, kierunek indywidualnie spersonalizowanej terapii. I to jest istotne wyzwanie przyszłościowe.

\section{0 years - from Roentgen's discovery to stereotactic radiosurgery}

This paper presents some details concerning the first few years after discovery of X-rays by Roentgen. Progress in radiotherapy during 120 years is discussed and illustrated by diagrams of milestones in the physics, technology and methods of radiation therapy. Discussion is focused on two topics: "physics versus biology" and "empirical radiotherapy versus clinical trials". Evolution of radiotherapy has been based on the so-called "Paterson school" for the first 50 years which moved since 1968 into the "Fletcher school". Rationale of this school was based on experimental and clinical radiobiology studies carried out in the 1950s-1970s, recognised almost all mechanisms of tumour and normal tissue response to radiation. For over 80 years, retrospective clinical studies and empirical experience have built up the fundamentals of modern radiotherapy and have served to design clinical trials. However, many "evidence based trials" provide some uncertainties and offer only average results as guidelines to treat individual patients. Trials are critically discussed based on the results of the selected studies with suggestions for careful interpretation based on logic and practical common sense. Studies of molecular biology and genetics clearly show that each tumour has own individual "fingerprint", which moves all oncology including radiotherapy to individual personalised therapy. This is an important challenge for near future.

NOWOTWORY Journal of Oncology 2015; 65, 5: 373-382

Słowa kluczowe: odkrycie Roentgena, fizyka vs biologia, radioterapia empiryczna vs triale kliniczne Key words: Roentgen's discovery, physics vs. biology, empirical radiotherapy vs. clinical trials 


\section{Trochę historii}

W 1895 roku (8 listopada) Wilhelm Conrad von Roentgen odkrył zjawisko fizyczne, które kilka lat później nazwał promieniowaniem X. Minęło 120 lat. Trudno uwzględnić wszystkie odkrycia, pomysły, hipotezy i dokonania, dlatego ograniczę się do tych kluczowych, które stały się milowymi krokami postępu radioterapii w ciągu tych 120 lat.

Źródłem etymologicznym radioterapii jest łacińskie słowo "radiare”, które oznacza liniowe rozprzestrzenianie się promieni z jednego punktu (źródła). Z kolei "irradiate” oznacza skierowanie promieni na określony cel. Stąd staje się zrozumiałe, że „radioterapia" oznacza metodę leczenia przy użyciu promieniowania (jonizującego lub cząsteczkowego), a nie odbiornika radiowego.

Roentgen był zamkniętym w sobie introwertykiem, który niechętnie publicznie odsłaniał tajniki swoich badań. Był świetnym wykładowcą fizyki na Uniwersytecie w Wurzburgu. Ale do czasu. Nie znosił medialnego rozgłosu. Dopiero po pół roku udało się znanemu w świecie dziennikarzowi uzyskać zgodę Roentgena na wywiad, zatytułowany "Nowy cud w fotografii" [1, 2], który przebiegał mniej więcej tak:

(D) "Proszę opowiedzieć historię Pana odkrycia".

(R) "Nie ma żadnej historii - po prostu coś odkryłem".

(D) "l jak Pan sądzi co to może być?".

(R) "Ja nie sądzę - ja badam".

(D) "Czy to jest światło?"

(R) "Nie"

(D) "A może elektryczność?"

(R) "Nie, w żadnej znanej postaci".

(D) "To co to jest?"

(R) "Nie wiem".

(D) "Jaka jest zatem przyszłość dla Pana odkrycia?"

(R) "Nie jestem wróżbitą".

(D) "Czy będzie można robić zdjęcia żołądka, płuca, jamy brzusznej"?

Na myśl połknięcia lampy Crooka, Roentgen roześmiał się. (R) "Jak to zrobię, to Panu powiem, a teraz jestem zajęty".

Tak zakończył się pierwszy i jedyny wywiad Roentgena.

W styczniu 1896 roku Cesarz Wilhelm odznaczył Roentgena Pruskim Orderem Korony Drugiej Klasy (dość oszczędnie jak na Cesarza). Aby zilustrować własne odkrycie, Roentgen zaprosił znanego anatoma von Köllikera na podium i zademonstrował zdjęcie kości jego ręki. To była ostatnia prezentacja Roentgena. Poczuł się obrażony przez studentów, którzy uznali go za wyjątkowego „nudziarza bez polotu". Gdy w 1901 roku odbierał z rąk Króla Szwecji Nagrodę Nobla, poza krótkim podziękowaniem również nie wygłosił mowy, mimo że była ona przewidziana protokołem. W późniejszych latach okazało się, że Roentgen nie był jedynym zamkniętym w swoim świecie. Było ich więcej reagujących nadwrażliwością na uwagi otoczenia.

\section{Od aparatury rentgenowskiej i tubki radowej do noża cybernetycznego}

Odkrycia promieniowania $\mathrm{X}$, radu i polonu stały się kamieniami węgielnymi dla rozwoju teleradioterapii i brachyterapii oraz medycyny nuklearnej. Pomimo braku wiedzy o fizycznych właściwościach i skutkach odkrytych rodzajów promieniowania oraz o podstawach ochrony radiologicznej zadziwia niepohamowany pęd wykorzystania ich w praktyce. Niestety, był tragiczny dla leczących i leczonych (martwice i popromiennie indukowane białaczki). Dotknęły one prawie wszystkich radiologów i terapeutów przed rokiem 1920.

Już w pierwszych latach XX w. rad w postaci tubek zaczęto powszechnie stosować $w$ leczeniu raka szyjki macicy i skóry. Jako standardową jednostkę przyjęto tubkę $20 \mathrm{mg}$ radu i przez długie lata dawkowanie przeliczano w mggodzinach. Równocześnie zaczęto konstruować proste aparaty ortowoltowe, początkowo o bardzo niskich energiach, mierzonych napięciem lampy rentgenowskiej 20-40 kV (dla terapii kontaktowej), które z czasem wzrosło nawet do 450 kV. Godne podziwu są innowacje w wykorzystaniu takiej aparatury, tym bardziej, że przerastały możliwości technologiczne. W latach 20. Manchester i Middlesex stały się pionierskimi centrami radioterapii, tylko częściowo uzupełnionymi o Instytut w Villejuif (Paryż). Ralston Paterson w Christie Hospital w Manchesterze został uznany za "ojca" ówczesnej radioterapii, a opracowane przez niego reguły, metody i techniki stworzyły fundamenty "szkoły Patersonowskiej", która przez ponad 50 lat królowała w światowej radioterapii [3]. To w Manchesterze wdrożono (ryc. 1) już w latach 20. planowanie 3D, a patersonowską technikę "ognia krzyżowego" (cross-fire) można dzisiaj interpretować jako prekursora niekoplanarnej radioterapii 3D (pseudo IMRT). Pod koniec lat 20. Paterson i Meredith opracowali metody i techniki wykorzystania igieł radowych w uzupełniającej radioterapii nowotworów regionu głowy i szyi oraz piersi. Ta uzupełniająca terapia (boost) oferowała precyzję i skuteczność nie gorszą niż uzyskiwana dzisiaj przy użyciu wyrafinowanych przyspieszaczy liniowych. Kolejnym krokiem była konstrukcja w Middlesex „mini" bomby radowej, zawierającej od 1-6 g radu, co otworzyło drogę dla teleradoterapii. Jedna z ruchomych konstrukcji takiej bomby radowej (ryc. 2) do złudzenia przypomina nowoczesny „nóż cybernetyczny" (CyberKnife), a jej możliwości techniczne zbliżone były do terapii stereotaktycznej. Na myśl przychodzi opinia Adama Michałowskiego, polskiego radiobiologa o uznanej renomie międzynarodowej — "to nie aparatura inarzędzia, a twórczy umysł i wyobraźnia decyduja o postępie nauki i medycyny".

W latach 60. bomba kobaltowa zastępuje aparaturę rentgenowską. Kończy się era ortowoltażu. Stabilna wiązka promieniowania gamma o w miarę wysokiej energii (średnio $1 \mathrm{MV}$ ) monopolizuje radioterapię. W Polsce terapia ortowoltowa zanika powoli dopiero w latach 80-90. A szkoda, bo dla 


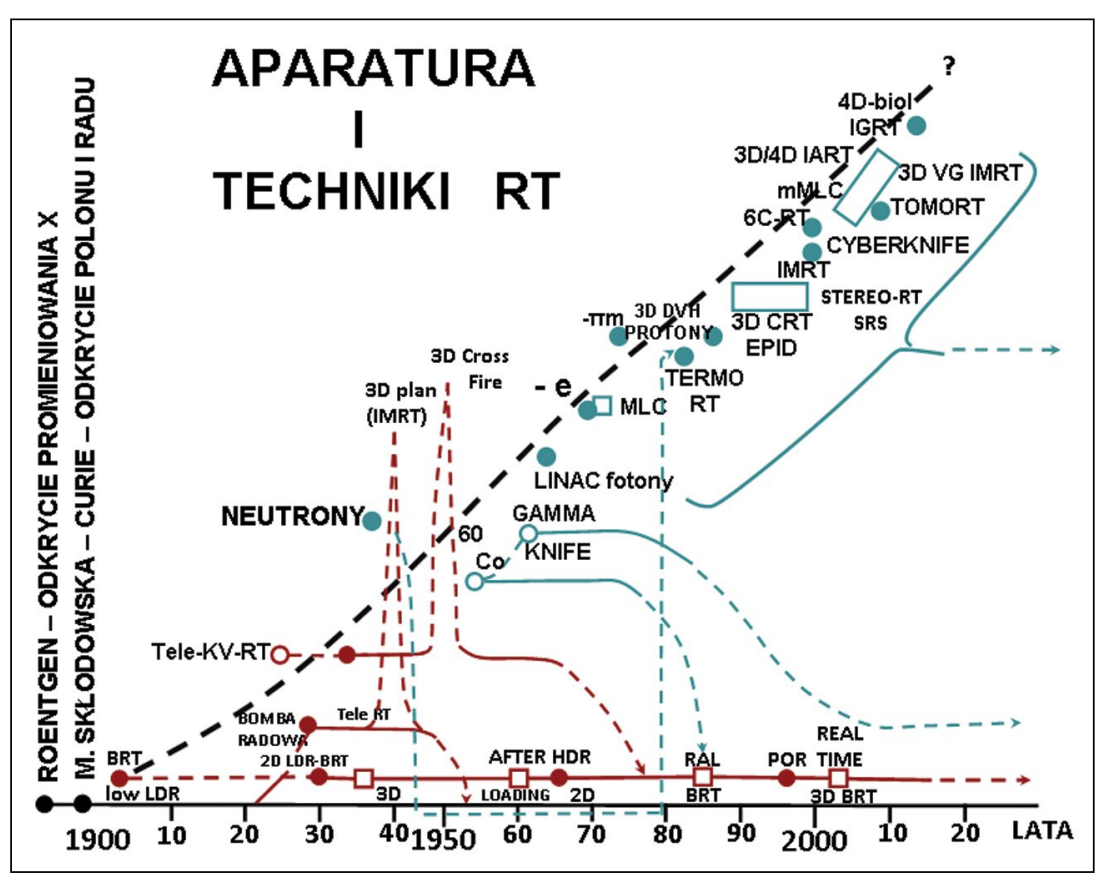

Rycina 1. Schemat postępu technologicznego i aparaturowego w radioterapii

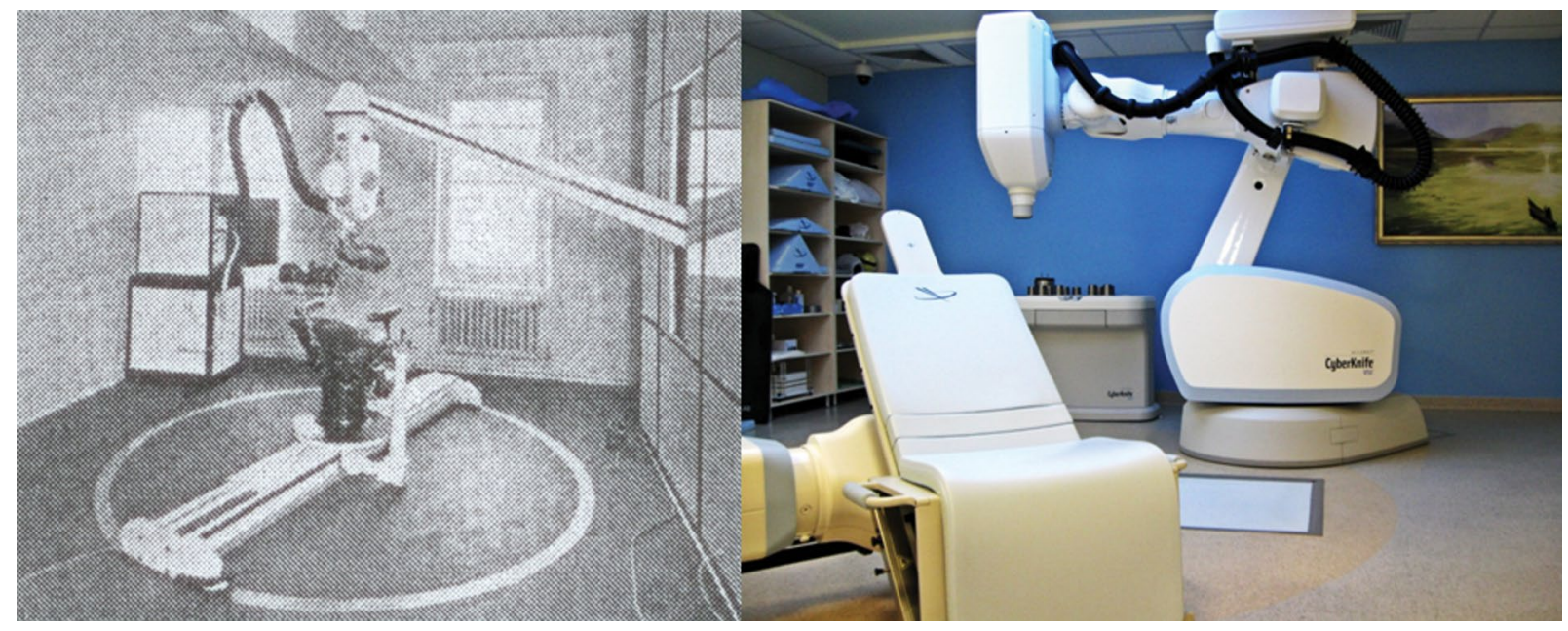

Rycina 2. Bomba radowa (Middlesex, lata 30.) przypomina przyspieszacz „nóż cybernetyczny” (lata 2000.)

raka skóry ortowoltaż i rad pod względem fizyki, skuteczności i niskich kosztów nie mają konkurencji. Również okres radu w brachyterapii dobiega końca. Zastępują go izotopy irydu, cezu i kobaltu (a na krótko kalifornu — promieniowania neutronowego). Brachyterapia wchodzi w erę źródeł o wysokiej mocy dawki (HDR), skracających czas leczenia. Nowoczesną wersją bomby kobaltowej staje się „GammaKnife", ale po fali entuzjazmu od lat 80-90 zaczyna zajmować pozycję "niszowq", nie obrażając jego użytkowników.

Od lat 70.,rynek" terapeutyczny opanowują przyspieszacze liniowe, oferując szeroki zakres energii promieniowania fotonowego i elektronowego (4-23 MV) oraz możliwość stosowania różnych, coraz bardziej wyrafinowanych technik napromieniania (ryc. 1).

Producenci prześcigają się w coraz nowocześniejszych, często zaskakujących rozwiązaniach technologicznych. To już nie tylko trój- i czterowymiarowe planowanie (3D/4D), ale i możliwość użycia technik IMRT, IGRT, IART, US-IMRT, VMAT, RapidArc, wizualizacji EPID, CBCT, BEV, dozymetrii in vivo, SBRT, cybernetycznej SRT, rozkładów objętościowych dawek (DVH). Nie ma sensu omawiania każdej z tych metod. Przy bogactwie repertuaru technologicznego i metodycznego pojawia się jednak pytanie: czy potrafimy go obecnie w pełni wykorzystać w praktyce. Okazuje się, że 


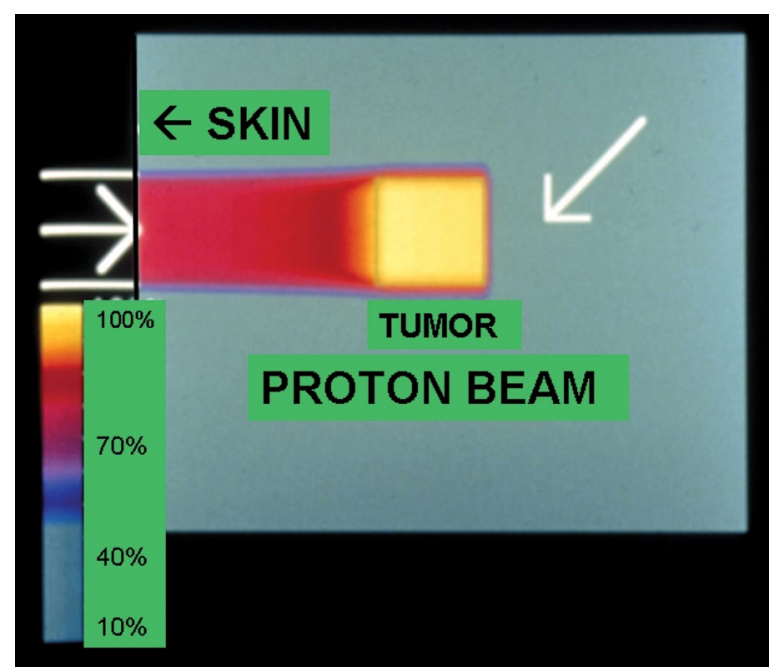

Rycina 3. Widmo wiązki protonowej z masywną koncentracją dawki w końcowym odcinku jej przebiegu (szczyt Bradda) z gwałtownym spadkiem do zera poza nim

przy stosowaniu technik modulacji intensywności dawki promieniowania (IMRT) postępujący gradient dawki na krótkim odcinku liniowym i w przestrzeni trójwymiarowej powoduje, że dawki w Gy przestają mieć wymiar fizyczny i stają się dawkami biologicznymi (izobioGy). Istotnego znaczenia nabiera przestroga Withersa "10 Gy nie zawsze jest równoważne 10 Gy, które niekoniecznie wynosi 10 Gy" [4]. To — w mojej opinii — jest głównym i aktualnym „principium” współczesnej radioterapii.

Już w połowie lat 30. badaczy zainteresowało promieniowanie cząsteczkowe - neutrony. Pierwsze próby kliniczne zakończyły się tragicznie (nie wiedziano, że dawki biologiczne były znacząco różne niż fizyczne). Przerwa w zainteresowaniu neutronami trwała około 50 lat (ryc. 1). Ta przestroga nie zamknęła jednak drzwi przed badaniami nad innymi rodzajami promieniowania cząsteczkowego. Potężne cyklotrony i synchrocyklotrony w USA, Japonii, Szwajcarii produkują różne cząstki, nie tylko elementarne. Od lat 60. zaczęto testować wszelkie możliwe rodzaje promieniowania: protony, cząstki a, ujemne mezony pi, jądra helu, neonu, argonu, krzemu, azotu, tlenu i węgla. Pomimo że tymi badaniami objęto 45000 chorych (!), większość badań miała charakter empiryczno-poznawczy, a ich przydatność utylitarna ograniczyła się, jak na razie, do wiązek protonowych i węglowych (Japonia), i to z szeregiem pytań oczekujących na odpowiedzi pomimo wyjątkowo atrakcyjnego rozkładu fizycznego tych rodzajów promieniowania (ryc. 3).

Technologia i aparatura to jedynie narzędzia, którymi od 120 lat dysponuje radioterapia. Rozwój tej dziedziny onkologii na przestrzeni dziesięcioleci należy w opinii H.D. Kaplana i H.D. Suita (obaj są laureatami Medalu Failla — najwyższego honoru w radioterapii) rozpatrywać $w$ dwóch kategoriach debat: „fizyka vs. biologia" $i$,/radioterapia empiryczna vs oparta na dowodach (EBO - Evidence Based Oncology)".

\section{Fizyka vs biologia}

Pierwszym śmiałkiem, który wykorzystał promieniowanie $X$ (nie mając żadnej wiedzy o jego właściwościach fizycznych), był Freund, podając w 1896 roku wysoką dawkę choremu na raka nosogardła [5]. Tak podają źródła. Nieoficjalnie, o czym rzadko się wspomina, rzeczywistym pionierem był Grubbe, który miesiąc wcześniej, po napromienianiu raka piersi, przemilczał jego skuteczność, a opisał jedynie silny martwiczy odczyn skóry [6, 7]. W ciągu 6 miesięcy po odkryciu Roentgena takich śmiałków było 10. Napromieniali różne zmiany skórne, czego skutkiem zawsze były silne odczyny popromienne. Pierwszym klinicznym dowodem kolejno ujawniających się odczynów skórnych, od rumienia - przez rozpływną epitheliolizę - do głębokiej martwicy skóry uda, był sam Becquerel, który grudki rudy uranowej nosił w kieszeni marynarki. Do kuriozalnych należy również zaliczyć pierwszy (1903) francuski eksperyment radiobiologiczny. Dwóm grupom szczurów wstrzyknięto w pachwinę prątki gruźlicy (nie wiadomo dlaczego w pachwinę i dlaczego gruźlicy). Jedną grupę napromieniano, a drugą nie. Szczury, które napromieniano, pozostały zdrowe (promienienie $X$ wybiły wszystkie prątki), a te, których nie napromieniano, zdechły z powodu gruźlicy. Uważano, że promieniowanie X leczy (wysusza) różne choroby, dlatego popularne stały się kąpiele, maści, inhalacje radonowe. Nie oceniając ówczesnych koncepcji badawczych, zainteresowanie odkryciami Roentgena i Marii Skłodowskiej-Curie było ogromne i wszechstronne.

Stosunkowo wcześnie, bo już w pierwszych latach XX w. wprowadzono w brachyterapii jednostkę 1 curie (1C) — aktywności źródła promieniowania (ryc. 4).W teleterapii było znacznie trudniej, bo tzw. dawkowanie odbywało się na zasadzie włączenia czasomierza i obserwowania zmian na skórze. Przyjmując za podstawowe kryterium zmianę koloru skóry (zaczerwienienie), wprowadzono tzw. „dawkę rumieniowq" = 1 Holtzknecht $(1 \mathrm{H})$, oznaczany metodą kolorymetryczną (do dzisiaj nie wiadomo, czy nie oceniano tego „na oko"). W latach 30. zaczęto stosować dozymetrycznie mierzoną dawkę ekspozycyjną promieniowania -1 rentgen (1R). Ta jednostka stała się podstawą wprowadzonych przez Patersona dawek letalnych dla guza (TLD), które obowiązywały w praktyce aż do końca lat 60 . Potem zastąpiono je dawką pochłoniętą, której jednostką był 1 rad (1r). Ponieważ wartości dawek całkowitych wyrażano w tysiącach radów, zastosowano ich "denominację", wprowadzając dawkę 1 gray (Gy), odpowiadającą 100 radom.

Coraz częstsze stosowanie różnych systemów frakcjonowania dawek spowodowało, że porównanie skuteczności biologicznej 60 Gy podanych w 30 frakcjach z dawką 60 Gy w 20 lub 40 frakcjach okazało się niemożliwe. Dlatego w uzupełnieniu dawek fizycznych zaczęto posługiwać się równoważnymi dawkami biologicznymi (NSD, TDF, CRE, NTD). 


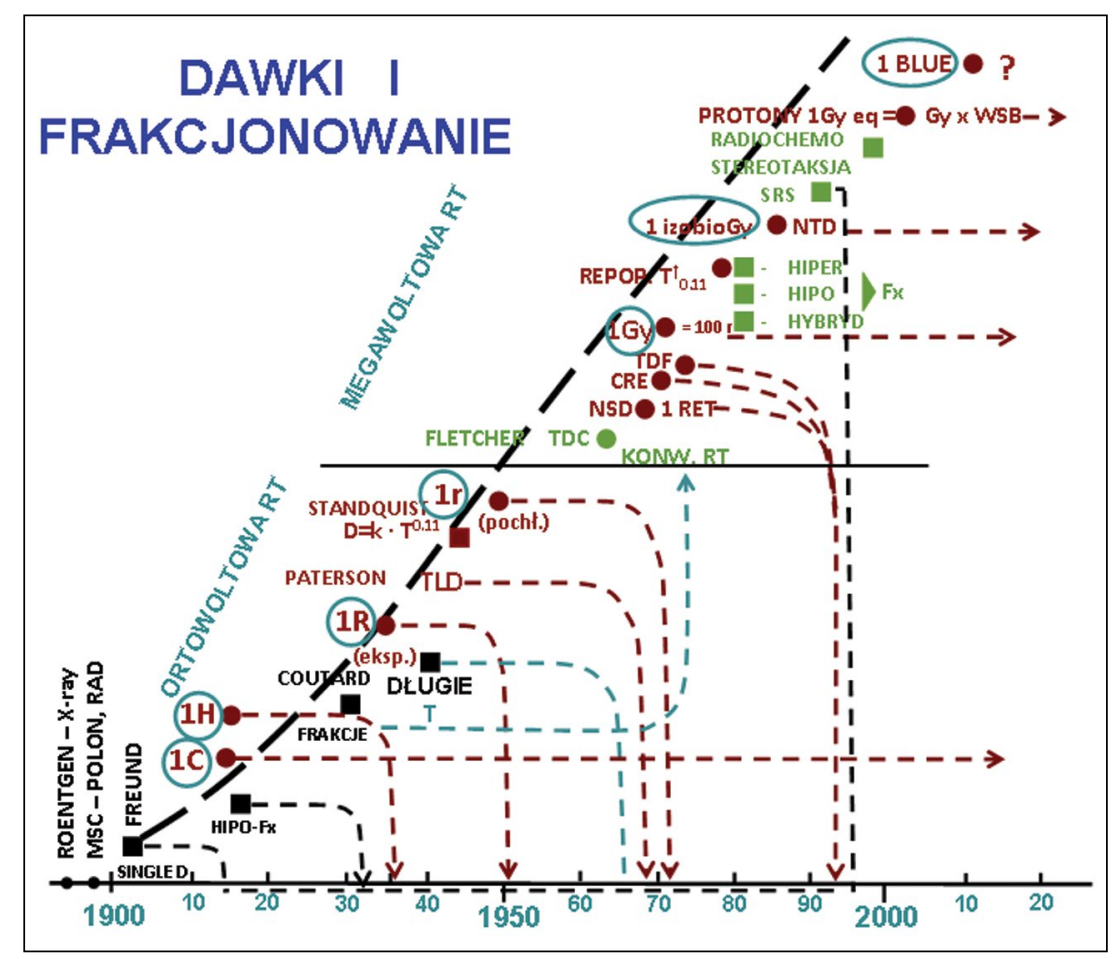

Rycina 4. Schemat postępu w definiowaniu dawek promieniowania i ich frakcjonowania

Przez prawie pięć dziesięcioleci dominowała „szkoła Patersonowska" wywodząca się z empirii klinicznej. Przełom nastąpił w 1968 r., po opublikowaniu przez Gilberta Fletchera „,Textbook of radiotherapy" [8]. Zasady radioterapii oparł on na rzetelnym i mierzalnym fundamencie radiobiologicznym, pisząc ",miejscowe wyjałowienie guza (nowotworowego) wymaga śmierci wszystkich jego komórek (kill them all)". Kolejne dawki frakcyjne $\left(d_{i}\right)$ eliminuja stały, niezmienny odsetek (nie liczbę) komórek, a o wysokości dawki całkowitej (TD) decyduje ich początkowa liczba, którq odzwierciedla wyjściowa objętość guza". Te trzy pryncypia przez lata były fundamentalnymi dogmatami w radioterapii (RT). Na przestrzeni lat ulegały korektom, bo okazało się, że śmierć, decydująca o miejscowym wyleczeniu, dotyczy „komórek klonogennych" i ostatecznie "macierzystych" (stem cells). Fletcher jest autorem podstaw radioterapii selektywnej, elektywnej, uzupełniającej (boost). Samodzielna i skojarzona RT stała się skutecznym narzędziem terapeutycznym. Gdyby jednak pokusić się o wybór jednego spektakularnego osiągnięcia w radioterapii, to niewątpliwie było to wprowadzenie przez Kaplana do leczenia ziarnicy złośliwej - oprócz chemioterapii — radioterapii techniką pól płaszczowych. Wyleczalność wzrosła z kilku do kilkudziesięciu procent.

Gilbert Fletcher był z urodzenia Francuzem, dość apodyktycznym, który w MD Anderson Cancer Institute w Houston potrafił stworzyć wokół siebie zespół wyjątkowych indywidualności i niezwykłych pionierów RT: Delclos, Montague, Milas, Thames, Withers, Suit, Peters. To oni wytyczyli kierunki rozwoju i postępu. Fletcher osiągnął prawie wszystkie zaszczyty. Anegdotycznie — do końca życia nie pozbył się francuskiego akcentu i jego największym zmartwieniem był fakt, że lokalna społeczność nie uznawała go za teksańczyka. Było to dla niego jak cierń. Dopiero gdy przeszedł na emeryturę, ktoś mu wyjaśnił, że w Teksasie trzeba mieć rancho i bydło. I Fletcher kupił małe rancho oraz 100 sztuk bydła. Wprawdzie nie wiadomo, jak dawał sobie radę z hodowlą, ale jego marzenie się spełniło - został uznany za „faceta z Texasu". Zmarł - jak wielu pionierów w radioterapii — na popromienną białaczkę.

„Fletcherowska" radioterapia nie powstałaby bez wcześniejszych odkryć i osiągnięć doświadczalnej i klinicznej radiobiologii $[5,7]$. W latach 50-70. odkryto i zbadano prawie wszystkie procesy i mechanizmy tłumaczące racjonalne podstawy klinicznej RT [4, 9-13]. W 1956 roku Puck i Markus jako pierwsi opracowali metodę ilościowego oznaczania biologicznej odpowiedzi na dawkę promieniowania, której wyniki przedstawili w formie „krzywej przeżycia komórkowego" [10]. Ten model, chociaż obecnie zmodyfikowany, do dzisiaj jest uznawany za uniwersalną metodę ilościowej, wymiernej oceny biologicznego efektu promieniowania jonizującego lub cząsteczkowego.

Od początku lat 50. kolebką prawie wszystkich odkryć radiobiologicznych staje się Gray Laboratory pod Londynem, który wciąga do badań ośrodki w Paryżu, Leuven, Houston, Stanford, Monachium, Aarhus, Amsterdamie. Scott, Elkind, Steel, Denekamp, Fowler, Withers, Peters, 
Alper, Adams, Gray, Thomlinsen, Steel, Begg, v.d.Kogel, Michałowski, v.d.Schueren, Milas, Thames, Hall. Trott, Barendsen, Tubiana, Malaise - to "creme de la creme" tych, którzy odkryli i wyjaśnili mechanizmy odpowiedzi guzów i tkanek zdrowych na napromienianie. Uszkodzenia subletalne, redystrybucja, efekt tlenowy i reoksygenacja, hipoksja, hierarchiczna i elastyczna organizacja szeregowych i równoległych podjednostek czynnościowych (FSU) tkanek zdrowych, wewnątrzkomórkowa promieniooporność - to tylko niektóre z podstawowych mechanizmów decydujących o różnicy w odpowiedziach na promieniowanie guza nowotworowego i zdrowych tkanek [14].

Badania nad efektem tlenowym zaowocowały próbami terapii hiperbarycznej (HBO) oraz z wykorzystaniem chemicznych radiouczulaczy (Adams). Badania nad mechanizmami przyspieszonej repopulacji komórek nowotworowych w trakcie RT, w których autor brał udział, dowiodły, że czas (OTT) był zbyt lekceważony w konwencjonalnej RT iże pod koniec 5-7 tygodnia napromieniania znaczący efekt letalny części podanych dawek $\left(\mathrm{d}_{\mathrm{i}}\right)$ zostaje zniwelowany przez intensywną repopulację przeżywających komórek klonogennych [15-17]. Przekonanie, że czas stał się jednym z zasadniczych determinant skuteczności RT, skutkowało od początku lat 80. podjęciem licznych kontrolowanych, randomizowanych badań klinicznych nad zmiennymi sposobami frakcjonowania dawki promieniowania w poszukiwaniu „Świętego Graala", tj. najbardziej skutecznej metody dawkowania, głównie dla nowotworów regionu głowy i szyi [18]. Aby nie powtarzać tylu słów dla określenia tych badań, w dalszej części tekstu posłużę się słowem "trial" (chociaż nie jest ono zbyt zręczne, bo również oznacza proces sądowy). Pojawiły się systemy hiper-, hipo-, przyspieszonego dynamicznego frakcjonowania ze zmienną $\mathrm{d}_{\mathrm{i}} \mathrm{w}$ trakcie napromieniania, z planowaną przerwą (split) lub bez przerwy, $z$ użyciem nawet 8 małych dziennych $d_{i}<1,5$ Gy [14]. Te badania trwały ponad 25 lat.

W związku z upowszechnieniem różnych metod frakcjonowania dawki od połowy lat 40. poszukiwano matematycznych formuł oznaczenia dawek biologicznie równoważnych (Strandquist, NSD, TDF, CRE).W dłuższej perspektywie czasu żadna z tych formuł nie spełniła oczekiwań radioterapeutów. Przełomem stało się w latach 70. zwrócenie uwagi przez Steela, Withersa, Petersa i Fowlera $[17,18]$ na wskaźnik $\alpha / \beta$, ilościowo opisujący indywidualną wrażliwość różnych nowotworów i tkanek zdrowych na zmianę wartości dawki frakcyjnej $\left(\mathrm{d}_{\mathrm{i}}\right)$, a nie ich promieniowrażliwości. Doceniając adaptowaną z doświadczalnej radiobiologii praktyczną przydatność modelu liniowo-kwadratowego (L-Q, model $\alpha / \beta$ ) dla oznaczenia dawek równoważnych biologicznie, największą wartościową konsekwencją wdrożenia tej koncepcji w klinice była zmiana kolejności i znaczenia fizycznych parametrów z dawki całkowitej (TD) i liczby frakcji (N) jako wiodących na dawkę frakcyjną $\left(\mathrm{d}_{\mathrm{i}}\right)$ jako parametr decydujący o wyborze wartości pozostałych. W odniesieniu do wyrafinowanych technik IMRT, IGRT, IART itp. ta zmiana okazała się wyjątkowo trafna i w pełni uzasadniona.

Pod koniec lat 90. spośród wielu interesujących doniesień i obserwacji dwie można uznać za przełomowe. Pierwsza (ryc. 5) dotyczy doniesienia Fowlera i Rittera, wskazującego na nieoczekiwanie niską wartość wskaźnika $\alpha / \beta$ ( $\leq 1,5 \mathrm{~Gy}$ ) dla raka prostaty (dotychczas dla raków przyjmowano wskaźnik $\alpha / \beta \geq 10 \mathrm{~Gy}$ ). Pomijając dyskusję nad wiarygodnością tego wyniku, był on podstawą dla powrotu do hipofrakcjonowania, tj. 1-5 wysokich dawek frakcyjnych (4,5-22 Gy!) i krótkiego czasu leczenia. Przed wielu laty Fowler wyraził dość proroczą opinię, że radioterapia ma charakter "round game". Coraz większe zainteresowanie hipofrakcjonowaniem jest niejako symbolem zakreślenia

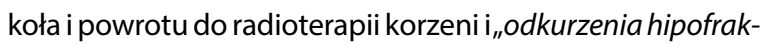
cjonowania", ale w wyrafinowanej wersji. W konsekwencji dynamicznie rozwija się stereotaktyczną radioterapię mózgu i pozaczaszkową (płuco, prostata, trzustka, wątroba, ogniska przerzutowe).

Drugim przełomowym krokiem było podważenie panującego dogmatu, że odpowiedź nowotworu na napromienianie reprezentuje wywodząca się od Pucka i Marhusa jedna krzywa przeżycia komórkowego (ryc. 6).W rzeczywistości jest to indywidualnie zmienny zbiór krzywych przeżycia komórkowego, opisujących różne komponenty komórkowe nowotworu. Ma to zasadnicze znaczenie dla planowania RT. Obecnie użycie radioznaczników dla komórek klonogennych, hipoksycznych, apoptycznych i macierzystych stwarza możliwość fuzji obrazowej (TK-NMR-PET), komórkowej struktury nowotworu w celu wykorzystania wyrafinowanych technik planowania 3D/4D, umożliwiających indywidualne modelowanie i modyfikowanie rozkładu dawek promieniowania.

Na przestrzeni 120 lat postęp intelektualny i technologiczny w zakresie fizyki, radiobiologii, biologii molekularnej i radioterapii osiąga obecnie coraz wyższy poziom. Osąd, że potrafimy je dzisiaj w pełni wykorzystać, byłby nadmiernym optymizmem.

\section{Radioterapia empiryczna vs oparta na dowodach}

Treść tej części, pomimo że jest oparta na faktach, może być uznana za kontrowersyjną, szczególnie przez zwolenników triali i głębokiej wiary w evidence based oncology (radiotherapy). Nie jest moim zamiarem „wkładanie kija w mrowisko", ale prezentacja dwóch, niekoniecznie przeciwnych stanowisk.

Radioterapia w pierwszych 60 latach była prawie wyłącznie oparta na empirii klinicznej. Jeszcze w latach 70. Fowler pisał: „Gdyby radioterapeuci czekali na w pełni naukowo udokumentowane dowody w radioterapii, leczenie pierwszego pacjenta jeszcze by się nie rozpoczęło". Empiryczna radioterapia opierała się na gromadzonym doświadczeniu i doskonaleniu umiejętności klinicznych. Od początku była ona obarczona 


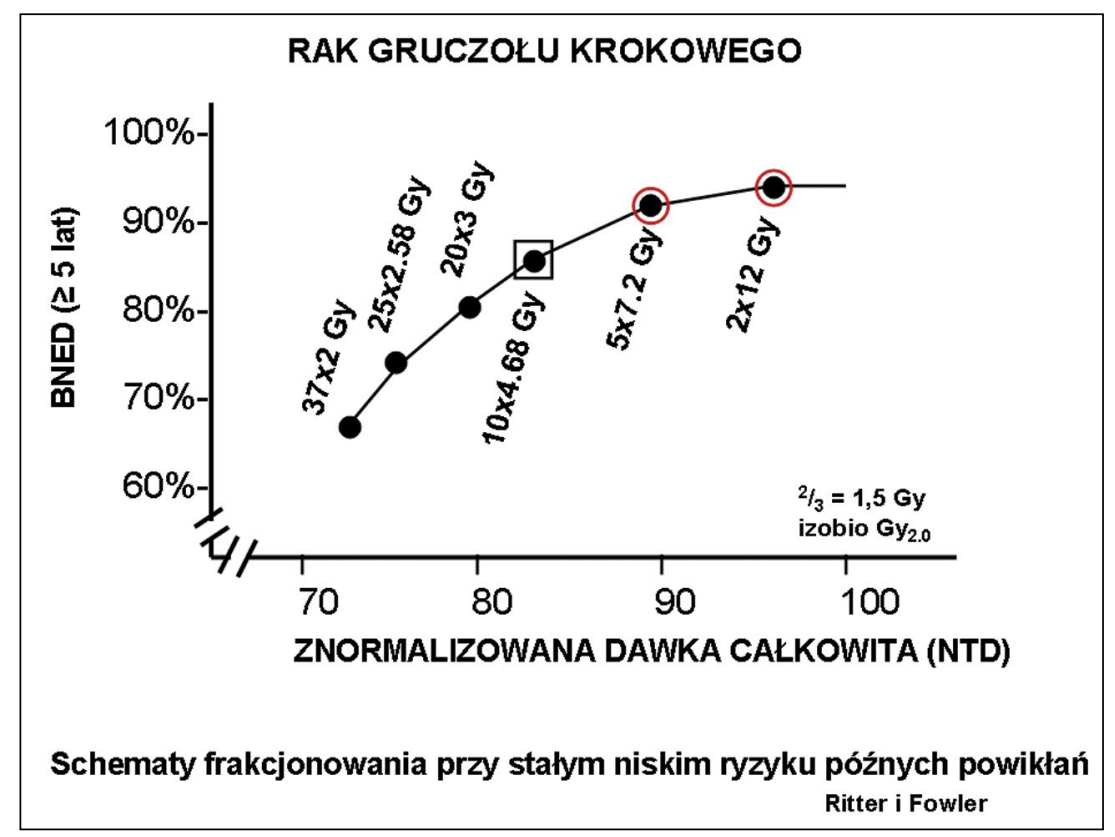

Rycina 5. Skuteczność radioterapii raka prostaty w funkcji różnych systemów frakcjonowania dawki (dla wskaźnika $\alpha / \beta=1,5$ Gy)

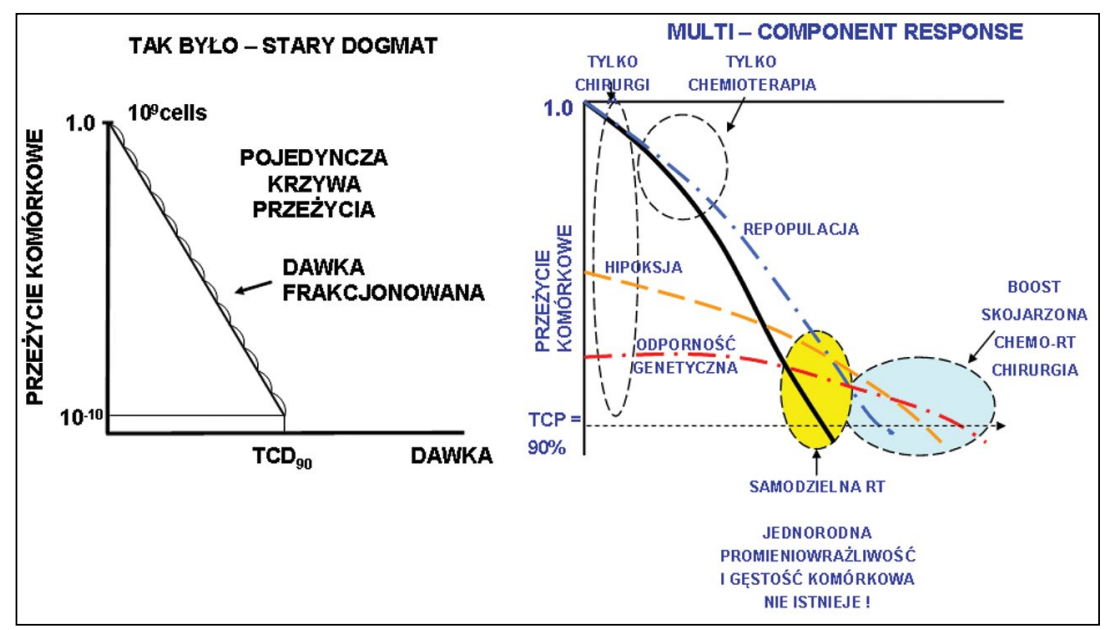

Rycina 6. Zastąpienie dogmatu, że jedna krzywa przeżycia (strona lewa) reprezentuje odpowiedź nowotworu na dawki promieniowania zastąpił zbiór krzywych przeżycia (strona prawa), które wymagają modelowania dawki (dose painting) w zależności od indywidualnej biologicznej charakterystyki komórkowej guza

niezamierzonymi błędami, nierzadko spowodowanymi niedostatkiem wiedzy $[4,19,20]$. Niebezpieczeństwo ciężkich powikłań wynikające ze stosowania pojedynczych dawek promieniowania rentgenowskiego przyczyniło się do dzielenia (frakcjonowania) dawki na mniejsze i dawka całkowita była ich sumą. Pionierem tej metody w latach 30. był Coutard, który zaproponował frakcjonowaną radioterapię na podstawie obserwacji klinicznych, a nie planowanych triali. Źródłem innowacji w radioterapii, przynajmniej do lat 60., były serie analiz retrospektywnych, często pochodzących z jednej instytucji. Obejmowały one szeroki zakres stosowanych dawek frakcjonowania i czasu leczenia. Wtedy nikt nawet nie śnił o trialach klinicznych.
W gliwickim i krakowskim Instytucie Onkologii zebrano ponad 1000 przypadków raka skóry napromienianych w latach 60. -80. jednym z 8 różnych sposobów frakcjonowania dawki, w tym również dawkami jednorazowymi. W oparciu o ten unikalny, retrospektywny zbiór danych klinicznych podważono formułę Strandquista i wykazano, że wydłużenie czasu leczenia (OTT) wymaga podania znacznie wyższej dawki całkowitej niż ta wyznaczona z formuły Strandquista. Był to pierwszy pośredni sygnał kliniczny wskazujący na znaczenie repopulacji, której w owych czasach w ogóle nie brano pod uwagę. Dowiedziono, że wyjściowa objętość guza nowotworowego jest fundamentalnym kryterium wyboru dawki i sposobu jej frakcjonowania dla uzyskania 
najwyższej szansy wyleczenia (a nie zaawansowanie TNM), które niestety ciągle dominuje w praktyce. Po raz pierwszy w piśmiennictwie dane z tego zbioru posłużyły do wyznaczenia wartości wskaźnika $\alpha / \beta$ dla skóry i raka skóry i do skonstruowania pierwszej klinicznej krzywej przeżycia komórkowego. Rak skóry posłużył zatem jako wszechstronny kliniczny model radiobiologiczny. Uzyskanie tak istotnych dla kliniki wniosków w oparciu o triale było i jest niemożliwe.

To nie jedyny przykład empirii klinicznej. Ponad 800 danych dotyczących raków regionu głowy i szyi napromienianych w Gliwicach w latach 1965-1980 stanowiło retrospektywneźródło wiedzy o przyspieszonej repopulacji izasadniczo zmieniło podejście radioterapeutów do znaczenia czynnika czasu [14-17]. To wnioski z tych badań, a nie triale, stanowiły podstawę dla badań klinicznych nad szerokim repertuarem nowych, zmiennych systemów frakcjonowanej radioterapii.

Do badań o wyjątkowej wartości klinicznej należy również zaliczyć przeprowadzoną przez Hellmana i Heimana z Chicago w 2001 roku retrospektywną analizę ponad 2000 przypadków raka piersi we wczesnym stopniu zaawansowania ( $T<2,5 \mathrm{~cm}$ N0M0) pod kątem ryzyka wczesnego rozsiewu ( $<1,5$ roku po leczeniu). Autorzy zdefiniowali profil molekularny guzów ( $\downarrow$ nm23, $\uparrow$ E-Kadheryna, $\downarrow$ Katepsyna D, $\downarrow$ Cyklina D1) o wyjątkowo korzystnej prognozie i bardzo niskim ryzyku wczesnego rozsiewu jako kandydatów do oszczędzającego leczenia, w przeciwieństwie do profilu guzów ( $\uparrow$ nm 23, $\downarrow$ E-Kadheryna, $\uparrow$ Katepsyna D, $\uparrow$ Cyklina D1, aneuploidia), dla których prognoza ryzyka rozsiewu wynosi ponad 60\%, które powinny kandydować do bardziej agresywnej terapii. Pomimo upływu 14 lat wyniki tego badania, wskazujące na celowość modyfikacji podejścia terapeutycznego do grupy chorych na raka piersi w zależności od profilu molekularnego, nie doczekały się dotychczas weryfikacji klinicznej.

Pomimo że empiria kliniczna wynikająca głównie z ocen retrospektywnych była i jest istotnym motorem postępu w radioterapii, to i tak przeważa opinia, że podstawą standardów terapeutycznych są i będą randomizowane triale jako źródło „evidence based oncology” (EBO). Czy aby na pewno? Bentzen, który jest niewątpliwym zwolennikiem EBO, jednocześnie zgłasza wątpliwość: „dowód braku znamienności niekoniecznie jest brakiem dowodu". Glatstein ${ }^{1}[19,20]$ idzie dalej i przestrzega, że "chociaż żyjemy w świecie, w którym decyzje oparte na dowodach sa powszechnie akceptowane, to należy ostrożnie ważyć i oceniać dowody (caveat emptor —wwolnym tłumaczeniu: bądźświadom ograniczeń) i unikać kategorycznych wniosków. Należy właściwie interpretować zwiq̨zek między znamiennością (p) i znaczeniem klinicznym, które często się różnią. Logika izdrowy rozsądek znaczq więcej niż wartość (p) i dowód, co nie oznacza, że można te drugielek-

\footnotetext{
${ }^{1}$ Glatstein wraz z Rubinem, Kaplanem i De Vitą są uznanymi liderami
} i autorytetami światowej onkologii. ceważyć. Należy pamiętać, że mając silną kartę, można przegrać, i odwrotnie: mając słaba kartę, można wygrać, oraz że wonkologii wielu chorych już od początku jest poza wszelkimi dostępnymi „dowodami". Statystyczna znamienność $(p<0,05)$ niekoniecznie i nie zawsze wyrokuje o znaczącej sile klinicznej badanego zwiq̨zu przyczynowo-skutkowego". Swój krytyczny komentarz Glatstein kończy pozornie żartobliwym stwierdzeniem, że „... spotkaliśmy ostatnio wrogów i okazało się, że to jesteśmy my...."

Pojawia się zatem pytanie: czy dowód o znamiennym zysku terapeutycznym jest na tyle istotny klinicznie, że upoważnia do zmiany taktyki terapeutycznej? Jeżeli taki zysk wynosi kilka procent, i to dla dużej grupy chorych, to odwrotną stroną medalu jest wątpliwość, czy w odniesieniu do pozostałej kilkudziesięcioprocentowej grupy chorych użycie badanej metody leczenia jest też uzasadnione.

Jak należy zatem interpretować wyniki triali w radioterapii? W latach 60.-70. do 7 brytyjskich triali dotyczących radioterapii w nadciśnieniu tlenowym (HBO) włączono łącznie 1100 chorych (raki płuca, głowy i szyi, pęcherza moczowego, szyjki macicy). Odnotowano niższy od spodziewanego, ale znamienny zysk terapeutyczny, głównie dla raka szyjki macicy. Jednak nie można było rozstrzygnąć, czy był on wynikiem nadciśnienia tlenowego czy też użycia wysokich dawek frakcyjnych. Badania przerwano z powodu trudności w rekrutacji chorych w związku z pojawieniem się na rynku badawczym chemicznych radiouczulaczy komórek hipoksycznych z grupy nitroimidazoli (misonidasol). Początkowa fascynacja opadła, bo okazało się, że zysk terapeutyczny ujawnia się dopiero po zastosowaniu wysokich dawek nitroimidazoli, a takowe wywoływały nieakceptowalny, wysoki odsetek ubocznych efektów neurotoksycznych. Również te badania miały swój koniec.

Jedną z interesujących klinicznie inicjatyw naukowych w latach 80 . było podjęcie przez czołowe ośrodki europejskie i amerykańskie badań nad metodami zmiennego frakcjonowania dawki, głównie w leczeniu raków regionu głowy i szyi. W okresie ponad 25 lat przeprowadzono ponad 50 wieloośrodkowych triali, rekrutując do nich ponad 15000 chorych. Spodziewano się uzyskać „złoty standard”, który przyniesie ponad 20-procentowy wzrost wskaźnika miejscowego wyleczenia. Niestety, metaanaliza uzyskanych wyników przyniosła rozczarowanie. Okazało się, że spośród tych triali tylko niecałe dwadzieścia spełniło rygory metaanalizy. Średni zysk terapeutyczny wyniósł zaledwie 6\%.,Tyrania mediany", jak pisze Glatstein. Użyciejednego punktu z krzywej przeżycia jako "dowodu" w prognozowaniu szansy wyleczenia u indywidualnego pacjenta jest mało przekonujące". Co zawiodło? Już na wstępie osiągnięcie jednego założonego skutku było prawie nieprawdopodobne, bo do triali kwalifikowano przypadki raka o różnej lokalizacji i zaawansowaniu, od T2N0 do T4N3. Przy tak dużej klinicznej różnorodności nawet najbardziej rygorystyczna randomizacja i stratyfika- 
cja nie zapewniły w badanych ramionach triali wymaganej jednorodności klinicznej, a co dopiero biologicznej (caveat emptor)! Szeroki zakres stosowanych dawek frakcyjnych, całkowitych, rytmu i czasu leczenia uniemożliwiał rozdział efektu dawki od efektu czasu. Wysiłek 25 lat i ponad 50 triali zakończył się średnim 6-procentowym zyskiem terapeutycznym wg EBO. Tymczasem w 3 trialach (DAHANCA, CHART, CAIR) odnotowano, w wyselekcjonowanej grupie chorych (wg profilowania molekularnego), 20-30-procentowy zysk terapeutyczny. Z testowanych różnych sposobów frakcjonowania w codziennej praktyce przyjął się w zasadzie jeden, tzw. "concomitant boost" - stosowanie dwóch dziennych dawek frakcyjnych w 2-3 ostatnich tygodniach leczenia oraz CHART i CAIR w niektórych ośrodkach.

Innym przykładem wątpliwej wiarygodności były triale, których celem była ocena celowości pooperacyjnej radioterapii raka płuca (PORT). Ujemne wyniki triali PORT podważyły celowość tej metody leczenia uzupełniającego. Dodatkowo legitymował je nonsensowny wniosek, że zwiększenie dawki skutkuje zmniejszeniem szansy wyleczenia. Te wnioski jako dowód EBO okazały się błędne, ponieważ same założenia triali były błędne. Thames zwrócił uwagę na fakt włączenia do metaanalizy przypadków napromienianych zarówno przestarzałą technologicznie bombą kobaltową i techniką 2D jak również przyspieszaczem liniowym i techniką 3D. Po odrzuceniu tradycyjnej terapii kobaltowej i selekcji przypadków leczonych wyłącznie przyspieszaczami liniowymi i techniką 3DThames wykazał 10-procentowy zysk terapeutyczny pooperacyjnej radioterapii. Jakie pytanie, taka odpowiedź. Zdziwienie może budzić fakt, że opracowania Thamesa, podważające wyniki metaanalizy, nie przyjęto do druku.

W świetle gromadzonej wiedzy z zakresu biologii molekularnej i genetyki nowotworów za słuszną należy uznać opinię Ridera (1991), że „natura sama w sobie jest nieubła- ganie nieliniowa". Skoro ludzie jako gatunek są genetycznie i biologicznie niejednorodni, to i nowotwory, które się u nich rozwijają, są również nieliniowo heterogenne. Istnieje zatem tyle biologicznych odmian nowotworów, również w grupach o tej samej histologii i zaawansowaniu, ile jest ludzi dotkniętych tą chorobą. W badaniach doświadczalnych in vitro i in vivo można zapewnić jednorodność grup badanych komórek lub zwierząt pochodzących z chowu wsobnego. W klinice jest to nieosiągalne (podobno było tak w Starożytnym Egipcie).W tej sytuacji przekonanie, że randomizacja i stratyfikacja w trialu może zapewnić oczekiwanąjednorodność grup badawczych, jest naiwne. Włączenie do badań chorych o tej samej histologii i lokalizacji nowotworu, ale o różnym zaawansowaniu TNM, tej oczekiwanej jednorodności również przeczy. Nawet w obrębie tej samej kategorii zaawansowania T wyjściowa objętość nowotworów, a zatem i liczba komórek, może się znacząco różnić, nawet 8-krotnie. W tej sytuacji, jeżeli w grupie stosuje się stałą i taką samą dawkę całkowitą i system frakcjonowania, wskaźnik wyleczalności będzie zależeć od liczbowej przewagi „mniejszych lub większych” guzów. Tak więc wyniki triali klinicznych jako źródła EBO trudno uznać za jedyną wykładnię dla planowania skutecznej terapii. Nie należy ich lekceważyć, ale uzbroić się w logikę i zdrowy rozsądek kliniczny — jak to sugeruje Glatstein.

\section{0 lat - i co dalej? ...}

Porównanie trzech głównych źródeł informacji zzakresu radioterapii, tj. konwencjonalnej (empiria kliniczna), przyspieszonej/hiperfrakcjonowanej (randomizowane triale) i stereotaktycznej hipofrakcjonowanej (ciągle głównie empiria kliniczna) wskazuje na ciągłą poprawę skuteczności (głównie empirycznej) tej metody leczenia na przestrzeni 120 lat (ryc. 7). Z praktycznego punktu widzenia można odnieść wrażenie, że długa, 5-7-tygodniowa radioterapia

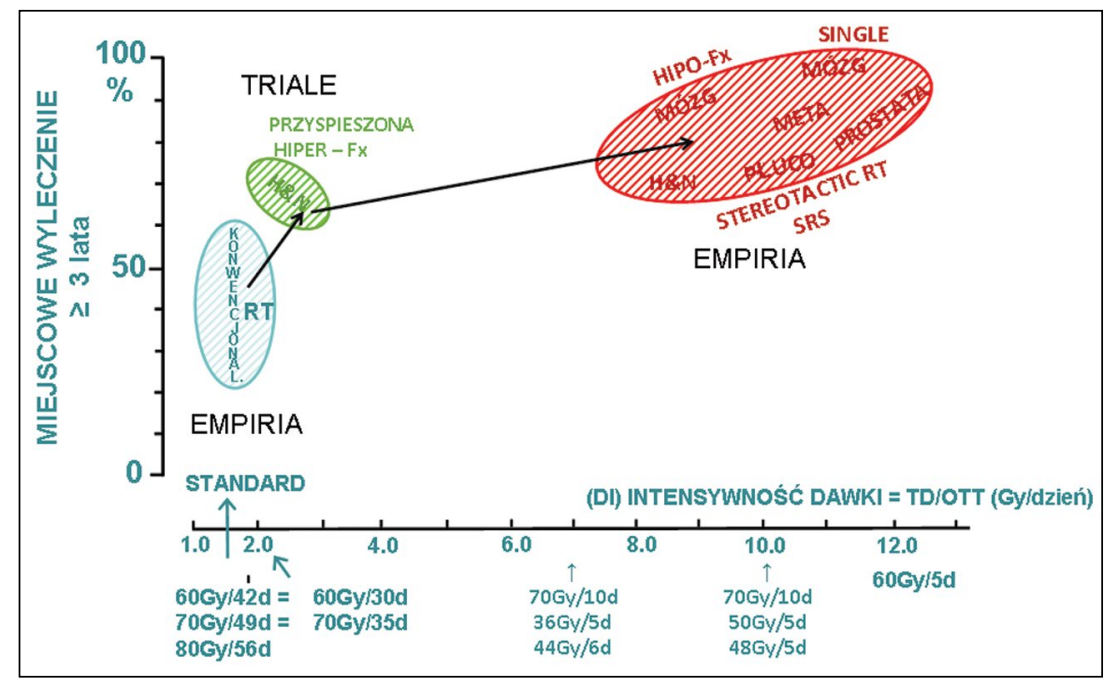

Rycina 7. Skuteczność radioterapii na przestrzeni dziesięcioleci — konwencjonalnej (empirycznej), niekonwencjonalnej (evidence based) i stereotaktycznej hipofrakcjonowanej (głównie empirycznej) 
staje się powoli „passé" na rzecz krótkiej, hipofrakcjonowanej stereotaksji, przynajmniej dla wybranych lokalizacji i rodzajów nowotworów. Również obszar, w którym króluje samodzielna i wyłączna radioterapia, coraz bardziej się kurczy na rzecz indywidualnego leczenia skojarzonego, w którym miejsce RT w sekwencji metod terapeutycznych staje się coraz bardziej indywidualnie zmienne. Indywidualna terapia celowana oparta na biologicznym obrazowaniu guza nowotworowego jest naukowym, intelektualnym i klinicznym wyzwaniem. Coraz większa indywidualizacja strategii leczenia ogranicza, a w moim przekonaniu wręcz uniemożliwia utworzenie jednorodnych biologicznie grup chorych w trialach według ich tradycyjnych reguł. Czyż nie przyszedł czas na ich modyfikacje? Uśrednione drogowskazy i standardy terapeutyczne stają się niewystarczające dla oczekiwań leczonych i leczących.

Coraz częściej stosowanie wysoce skutecznej stereotaktycznej radioterapii z użyciem pojedynczych wysokich dawek lub kilku dawek frakcyjnych wskazuje, że w ciągu tych 120 lat od czasu wykrycia przez Roentgena promieniowania $X$ radioterapia zakreśla koło, powracając do empirii klinicznej panującej w radioterapii, do lat 60 . Pomimo ogromnego postępu technologicznego, metodycznego i biologicznego, który dokonał się w tym okresie, nabyte doświadczenie i umiejętności wydają się jeszcze niewystarczające dla pełnego wykorzystania zaoferowanych nowoczesnych narzędzi. Na zakończenie warto może zatem przytoczyć wypowiedź Ridera (2001): „Podczas gdy żaden z dowodów nie osiąga oczekiwanejznamienności statystycznej, nierzadko zdarzenia anegdotyczne mogą stać się początkiem odkrywczej hipotezy".

Prof. dr hab. n. med. Bogusław Maciejewski

Centrum Onkologii — Instytut im. Marii Skłodowskiej-Curie Oddział w Gliwicach

ul. Wybrzeże Armii Krajowej 15

44-100 Gliwice

e-mail:bmaciejewski@io.gliwice.pl

\section{Piśmiennictwo}

1. Dam HJW. The new marved in photography. Mc Clar's Magazine 1896; 6: 403-404.

2. Halperin EC, Perez CA, Brady LW. The discipline of radiation oncology. W: Perez and Brady's (red.) Principles and practice of radiation oncology,. $5^{\text {th }}$ ed. Philadelphia: Wolters Kluwer, Lipponcott Williams i Wilkins; 2004, 2-76.

3. Paterson $\mathrm{R}$. The treatment of malignant disease by radium and $x$-rays: being a practice of radiotherapy. Baltemore: Williams i Wilkins, 1948.

4. Withers HR. Failla memorial lecture. Contrarian concepts in the progress of radiotherapy. Radiat Res 1989: 119: 395-412.

5. Freund L. Elements of general radiotherapy for practitioniers. New NY: Rehman, 1904

6. Fritz-Niggli H. 100 years of radiobiology: implications for biomedicine and future perspectives. Experientia 1995; 51: 652-664.

7. Grubbe EH. Priority in the therapeutic use of x-rays. Radiology 1933; 21: 156-162.

8. Fletcher GH. Textbook of radiotherapy. Philadelphia: Lee \& Ferbiger 1966.

9. Bergonie J, Tribondeau L. Actions des rayons $\mathrm{X}$ sur le testicule du rat blanc. C. r. Soc Biol 1904; 56: 400-402.

10. Puck TT, Marcus PI. Action of x-rays on mammalian cells. J Exp/ Med 1956; 103: 653-666.

11. Regaund C. La radiosensibilitz des neoplasms melins dans ses relations avec la functuation de la multiplication allalaire. CR Soc Biol 1992; 86: 933-995.

12. Thomlinson RA. Changes of oxygenation in tumours in relation to irradiation. Front Radiat Ther Oncol 1968; 3: 109-112.

13. Steel GG. Basic clinical radiobiology. London, New York, Oxford Univ. Press, 1997.

14. McBride WH, Withers HR. Biological basis of radiation therapy. W: Perez and Brady (red.) Principles and practice of radiation oncology. $5^{\text {th }}$ ed. Philadelphia: Wolters Kluwer, Lipponcott Williams i Wilkins 2004; 76-108.

15. Maciejewski B i wsp. The influence of the member of fractions and overall treatment time on the local tumor control of cancer of the larynx. Radiation Oncol 1983; 3: 321-329.

16. Maciejewski B, Withers HR, Taylor JM i wsp. Dose fractionation and regeneration in radiotherapy for cancer of the oral cavity and oropharynx: tumor dose-response and repopulation. Int J Radiat Oncol Biol Phys 1989; 16: 831-843.

17. Withers HR, Taylor JM, Maciejewski B. The hazard of accelerated tumour clonogen repopulation during radiotherapy. Acta Oncol 1988; 27: 131-146.

18. Afamed A. Alered fractionation schedules. W: Perez and Brady (red.) Principles and practice of radiation oncology. $5^{\text {th }}$ ed. Philadelphia:Wolters Kluwer, Lipponcott Williams i Wilkins 2004; 300-320.

19. Glatstein E. Restrictions of a statistical mind: clinical relevance versus $\mathrm{p}$ values or when less is more. Int J Radiat Oncol Biol Phys 2007; 68; 322-323.

20. Glatstein E. Personal thoughts on statistics, or lies, damn lies, and (oncologic) statistics. Int J Radiat Oncol Biol Phys 2004; 58: 1329-1333. 